\title{
ECONOMIC ASPECTS OF WINE TOURISM SUSTAINABILITY AT A UNESCO WORLD HERITAGE REGION OF UPPER MIDDLE RHINE, GERMANY
}

\author{
Marc Dressler', \\ Ivan Paunović ${ }^{2}$
}

${ }^{1}$ Weincampus Neustadt, University of Ludwigshafen, Neustadt/Weinstrasse, Germany

${ }^{2}$ Weincampus Neustadt, Rural service center Rhenish Palatinate, Neustadt/Weinstrasse, Germany

\section{Correspondence:}

Ivan Paunović

e-mail:

ivan.paunovic@dlr.rlp.de

\begin{abstract}
:
The paper deals with sustainability aspects of wine tourism demand in the region of high natural and cultural distinctiveness, which has been recognized by UNESCO as world heritage. The paper primarily deals with the importance of sustainability on wine buying decision, as well as seasonality of wine tourism demand and awareness of the Middle Rhein as a wine region as three important economic aspects of wine destination sustainability. It also deals with the mode of arrival to the destination as an economic/environmental sustainability indicator. The results section finally presents in detail the visitor's travel and wine travel behavior as well as wine knowledge. The data was collected on the sample of $\mathrm{N}=400$ visitors at the destination of St. Goar-Loreley and presented as descriptive statistics. The results demonstrate the high importance of the sustainability aspect on the decision for buying wine, high yearly volatility of the wine tourism demand, high awareness of the Middle Rhine as a wine region although wine, culture, and education represents the smallest primary motivations for travel. The article postulates that sustainability needs to be included in the wider destination context, beyond the wine tourism focus only, in order to enhance the authenticity of sustainable wine tourism offer and protect the destination cultural and natural resources. In this sense, sustainable innovations at the intersection between heritage, wine and tourism should be encouraged in order to advance the management of resources of the Upper Middle Rhine Valley with the offer that matches the preferences of contemporary travelers and their expectations from a well-known tourist destination.
\end{abstract}

\section{Keywords:}

German wine tourism, regional development, sustainability, travel motives, consumer behaviour

\section{INTRODUCTION}

Sustainability, along with innovation and business strategy, represents one of the most important future research fields in wine tourism (Hall \& Prayag, 2017). However, in the UNESCO world heritage destinations, sustainability has only recently become an important platform and starting point for development and conservation and therefore different indicators for measuring sustainability are lacking and need to be developed for the three dimensions of sustainability-environmental, economic and social (UNESCO, 2017). This paper aims to bridge this gap by deploying three economic indicators-importance 
of sustainability on the wine buying decision, seasonality of wine tourism demand and awareness of the destination, as well as one economic/environmental indicator- the mode of arrival to the destination. These indicators related primarily to wine tourism are especially suitable for measuring economic sustainability at the St. Goar/Loreley as both a cultural and wine tourism destination. In the future this type of indicators can be applied to the whole destination of the Upper Middle Rhein Valley because wine tourism as an economic activity connects the world renowned natural heritage (steep Vineyards on the Rhein) with cultural heritage (castles and literary tourism- Loreley and Rhein romanticism) at the destination. The second reason is that wine production together with wine tourism represents an important part of the economy in the whole Upper Middle Rhein Valley. The Upper Middle Rhein Valley represents is a classic "old world" wine region. The 65 $\mathrm{km}$ long stretch of the Rhein Valley combines castles, historic towns, vineyards and most importantly legends that inspired artists and writers throughout the history (Germany, Hesse, \& Rhineland-Palatinate, 2002). The importance and synergetic effects of wine and viticulture landscapes on the Rhine river have also been recognized by the local tourism industry, which is why there is an intensive cooperation between tourism, wine marketing and wine industry (Tourismusstrategie Romantischer Rhein Unsere Handlungsempfehlungen, 2011). However, what makes the region stand out on the tourist map is the fact that the Upper Middle Rhein Valley is a birthplace of the art movement of the "Rhein romanticism" and as a part of this movement especially the internationally famous myth of the sorceress Loreley (Ministerium für Wirtschaft, 2013).

Having in mind the described challenges of measuring sustainability at the UNESCO world heritage destination of Upper Middle Rhein Valley, as well as the importance of wine both as an economic activity (wine production and wine tourism) and protected natural heritage (steep vineyards) as well as cultural heritage (praise of the Romantic movement for the wines of the Upper Middle Rhein Valley) the following 5 research questions have been defined:

1. What are the characteristics of demand for tourism/wine tourism of visitors at St. Goar/Loreley?

2. How big is yearly volatility of demand for wine tourism of visitors at St. Goar/Loreley?

3. How important is sustainability for wine demand among St. Goar/Loreley visitors?

4. How high is the awareness of the Upper Middle Rhein as a wine region among the visitors at St. Goar/ Loreley?

5. What is the mode of arrival to the destination of visitors to St. Goar/Loreley?

Sustainable tourism can be developed only by applying its principles on all parts of the tourism system as defined by Leiper (1979), and the first element in this process is understanding the characteristics of tourism demand, which is why sustainability of this element of the tourist system is so important (Dolnicar, Crouch, \& Long, 2008). Fighting the volatility of demand, by creating a targeted offer in the low demand months is one of important measures in enhancing the sustainability of tourism (Indicators of Sustainable Development for Tourism Destinations, 2004; Paunović, 2017; Paunović \& Jovanović, 2017). Means of transport at the destination is another important issue of the destination sustainability because it has been demonstrated this is an important issue for green tourists (Swarbrooke \& Horner, 2007). Creation of high-quality, sustainable products is important for sustainable destinations (Goeldner \& Ritchie, 2009; Maksin, Pucar, Korać, \& Milijić, 2009), but the question remains how important it is on the demand side of the wine tourism, as well as how well is the wine offer of the region of Upper Middle Rhein positioned in the minds of consumer/potential consumers. Another very important issue regarding sustainability of tourism is the means of transport on the destination.

\section{METHODOLOGY}

The research data has been collected via self-administered questionnaire in the paper form on the location of St. Goar/Loreley in the Middle Rhine Valley in the period June-July 2017. There were two locations for data collection: one location was in the center of St. Goar, while the other was on the other side of the river at the Loreley visitor center. Of the total sample size of $\mathrm{N}=400$, certain parts of the questionnaire (buying wine and tourist statistics) have been only filled in by suitable persons drinking wine ( $\mathrm{N}=363)$ and those who qualify as tourists in the destination $(\mathrm{N}=366)$. 
Research results cover two important areas: (a) basic tourist-related information (length of stay, type of accommodation, major motives for travelling), and basic wine-tourism related information (tourists living in the wine region, previous travel to a wine region, level of interest in wine, wine drinking frequency and level of knowledge about wine), as well as (b) sustainability indicators of wine tourism (wine tourism demand variability, important aspects influencing a wine buying decision, awareness of the Middle Rhine as a wine region, as well as mode of arrival to the destination).

\section{RESULTS}

Table 1 shows the basic tourist-related information (length of stay, type of accommodation, motives for travel) as well as basic wine-tourism related information (tourist living in a wine region, previous travel to a wine region, level of interest in wine, wine drinking frequency and level of knowledge about wine). That majority of tourists visit St. Goar/Loreley as a part of day trip, or excursion (72\%), followed by 2-3 days length of stay (17\%). Extended stays of four to seven days were only about $10 \%$. There were $\mathrm{N}=366$ tourists (presented later in Table IV) that were tourists in the region of Upper Middle Rhein as a wine region and therefore replied to the question about the awareness of the Upper Middle Rhein as a wine region, while $\mathrm{N}=34$ come from the region of Upper Middle Rhein, and can therefore be considered locals to the region, but on a visit to St. Goar/Loreley.

Regarding accommodation, most of tourists stay in hotels (41.3\%), followed by no overnight stay (18.6\%), and staying at a pension hotel (15.8\%). Other, less popular overnight arrangements include private accommodation (12.3\%), camping site (8.2\%), and wineries (3,8\%). Recreation (51.1\%) is the most popular motivation for travel, followed by hiking/bicycle travel (15\%), visiting friends/acquaintances/family (11.2\%), cultural/ educational travel (9.8\%) and wine travels (9.3\%). Other motives amount to $6 \%$, while $2.7 \%$ of tourist come because of a pre-booked group travel. More than $50 \%$ of the visitors does not live in a wine region, and most of the tourists have previously traveled to a wine region (70\%). More than half of tourist (54\%) have an average interest in wine, while around a quarter $(24.3 \%)$ have high interest in wine and a little less than a quarter $(21.8 \%)$ have a low interest in wine. More than one third (36,5\%) of the interviewed tourists drink wine several times a month. Only less than $10 \%$ of the tourists stated to never drink wine.

Table 1. Basic tourist-related information and wine tourism related information

\begin{tabular}{|c|c|c|c|c|c|}
\hline & $\mathbf{N}$ & Frequency & & $\mathbf{N}$ & Frequency \\
\hline Length of stay & 400 & & Living in a wine region & 400 & \\
\hline Day trip & & $71.9 \%$ & No & & $53 \%$ \\
\hline 2-3 days & & $16.9 \%$ & Yes & & $47 \%$ \\
\hline 4-7 days & & $11.2 \%$ & Previous travel to a wine region & 399 & \\
\hline Type of accommodation & 400 & & Yes & & $69.9 \%$ \\
\hline Hotel & & $41.3 \%$ & No & & $30.1 \%$ \\
\hline Not staying overnight & & $18.6 \%$ & Level of interest in wine & 400 & \\
\hline Pension hotel & & $15.8 \%$ & Low & & $21.8 \%$ \\
\hline Private accommodation & & $12.3 \%$ & Average & & $54 \%$ \\
\hline Camping site & & $8.2 \%$ & High & & $24.3 \%$ \\
\hline Winery & & $3.8 \%$ & Wine drinking frequency & 400 & \\
\hline Motives for travel & & & Several times a week & & $26.8 \%$ \\
\hline Recreation & & $51.1 \%$ & Several times a month & & $36.5 \%$ \\
\hline Hiking/bicycle travel & & $15 \%$ & Less than once a month & & $27.5 \%$ \\
\hline Visiting friends/acquaintances/family & & $11.2 \%$ & Never & & $9.3 \%$ \\
\hline Cultural/educational travel & & $9.8 \%$ & Level of knowledge about wine & 400 & \\
\hline
\end{tabular}




\begin{tabular}{lllc}
\hline Wine travel & $9.3 \%$ & None & $12.3 \%$ \\
\hline Other & $6.0 \%$ & Low & $51.8 \%$ \\
\hline Prebooked group travel & $2.7 \%$ & Good & $31.5 \%$ \\
\hline & & Very good & $4.5 \%$ \\
\hline
\end{tabular}

Table 2 illustrates the seasonality of visits to the destinations like St. Goar/Loreley with a strong summer season: May (12.7\%), June (21\%), July (13.7\%), August (12.7\%) and September (11.5\%). Preseason is in the months of March (4.7\%) and April (6.8\%), while the postseason is in October (6.1\%). Season with no touristic value is in the winter time: November (2.7\%), December (2.3\%) and January (2.4\%).

Table 2. Preffered months to visit destinations like St. Goar/Loreley

\begin{tabular}{lcc}
\hline \multicolumn{3}{c}{ Preferred months to visit destinations like St. Goar/Loreley } \\
\hline Janth & $\boldsymbol{N}$ & Percent \\
\hline February & 32 & $2.4 \%$ \\
\hline March & 44 & $3.3 \%$ \\
\hline April & 62 & $4.7 \%$ \\
\hline May & 90 & $6.8 \%$ \\
\hline June & 168 & $12.7 \%$ \\
\hline July & 277 & $21 \%$ \\
\hline August & 181 & $13.7 \%$ \\
\hline September & 168 & $12.7 \%$ \\
\hline October & 152 & $11.5 \%$ \\
\hline November & 80 & $6.1 \%$ \\
\hline December & 35 & $2.7 \%$ \\
\hline Total & 31 & $2.3 \%$ \\
\hline
\end{tabular}

Table 3 shows three important indicators of economic sustainability, all three measuring the tourist demand variability: the share of the business month in the overall yearly demand is $20,98 \%$, the share of the busiest three months in the overall yearly demand is $47.42 \%$, and the ratio of the busiest month to the least busy month inside a year is 8.93 .

Table 3. Wine tourist demand variability as a wine tourism sustainability indicator

\begin{tabular}{lc}
\hline \multicolumn{1}{c}{ Tourist demand variability } & Share/Ratio \\
\hline Share of the busiest month in the overall yearly demand & $20,98 \%$ \\
\hline Share of the busiest three months in the overall yearly demand & $47.42 \%$ \\
\hline Ratio of the busiest month to the least busy month inside a year & 8.93 \\
\hline
\end{tabular}

In table 4, data on three further indicators of wine tourism sustainability is presented: the importance of sustainability for wine buying decision, awareness of the Middle Rhein as a wine region and mode of arrival to the destination. The most important aspects influencing the wine buying decision stated were taste (32.7\%), 
price (16.8\%), grape variety (13\%), and sustainability (9\%). Following were labels, wine region, vintner, awards or brands. Most of interviewees are aware of the Middle Rhine being a wine region (74.3\%). Most of tourists come to the destination with a car $(62 \%)$, followed by a boat $(18 \%)$. Other modes include bicycle or motorbike tours. Only few tourists come with a bus $(3.6 \%)$ or by train $(3.3 \%)$.

Table 4. Indicators of sustainable wine tourism at the St. Goar/Loreley

\begin{tabular}{|c|c|c|c|c|c|}
\hline & $N$ & Frequency & & $N$ & Frequency \\
\hline $\begin{array}{l}\text { Important aspects influencing a } \\
\text { buying decision }\end{array}$ & 363 & & $\begin{array}{l}\text { Awareness of the Middle Rhine as } \\
\text { a wine region }\end{array}$ & 366 & \\
\hline Taste & & $32.7 \%$ & Yes & & $74.3 \%$ \\
\hline Price & & $16.8 \%$ & No & & $25.7 \%$ \\
\hline Grape variety & & $13 \%$ & Mode of arrival to the destination & 400 & \\
\hline Sustainability & & $9 \%$ & Car & & $62 \%$ \\
\hline Labels & & $7.1 \%$ & Ship/boat & & $18 \%$ \\
\hline Wine region & & $6.9 \%$ & Bicycle & & $6.6 \%$ \\
\hline Vintner & & $6.5 \%$ & Motorbike & & $6.6 \%$ \\
\hline Awards & & $4.1 \%$ & Bus & & $3.6 \%$ \\
\hline Brand & & $3.9 \%$ & Train & & $3.3 \%$ \\
\hline
\end{tabular}

\section{DISCUSSION}

A somewhat unexpected insight of the study was that sustainability ranked fourth most important factor influencing wine buying decision, before categories like labels, wine region, vintner, awards or brand, because some previous research in the US demonstrated no sales advantage of marketing wines as organic or sustainable, see Delmas and Grant (2008) as well as Atkin, Gilinsky Jr, and Newton (2011). There are also international differences in this sense, where only in Spain there are perceived benefits for branding from sustainabilityrelated winery activities, while in the US and Italy this is not the case (Gilinsky et al., 2015). However, research findings are consistent with the previous findings in Germany, where Klohr, Fleuchhaus, and Theuvsen (2014) have demonstrated that a growing number of wine consumers is interested in sustainability. However, in order to fully exploit this market opportunity in the wider context of wine tourism, not only products have to reflect sustainability, but also the wider destination, where sustainability of transport and accommodation are important parts of overall sustainability approach (Paunović \& Jovanović, 2017). In this sense, tourists arrive to the destination predominantly by car (62\%). This is an important aspect of future destination development, as a bridge has been planned for this location (Ministerium für Wirtschaft, 2013) and findings in this paper support the thesis that an enhanced car mobility would benefit greatly this UNESCO world heritage destination. However, in the long run, mobility needs to be also diversified to other more sustainable mobility solutions. Also, a very high ratio of the busiest month to the least busy month in the demand for wine tourism destinations like Upper Middle Rhein region (8.93) presents a clear case for introducing measures for attracting visitors in the off-season. For example, previous research demonstrated that this ratio is 5.83 in Kopaonik and 1.79 in Zlatibor (Paunović \& Radojević, 2014). Those are not comparable destination as these are both mountain destinations but can serve as a first reference for comparison.

Another important insight from the presented results is that they confirm the common hypothesis that both wine and cultural industries need to be considered as so-called second row tourism stakeholders (Pechlaner, Zacher, \& Paunovic, 2016). Both themes rank among the least important motives for visiting the destination where $9,3 \%$ of visitors name wine as a motive for travel, while 9,8\% name culture/education. This being said, the importance of wine and cultural tourists should not be underestimated, as both groups of tourists usually consist of an affluent population, and each one of these two tourist markets is therefore very competitive and requires careful development of appropriate offerings (Dreßler, 2016; Dressler, 2017; Paunovic, 2014). 
Literary tourism places, such as the famous Loreley rock, can present a powerful destination differentiator. This primarily social constructs are being purposefully conceived, interpreted and promoted to attract visitors (Herbert, 2001). This is why it is important that the uniqueness of the natural and cultural setting of the Upper Middle Rhine Valley has been proclaimed a UNESCO world heritage site (Ministerium für Wirtschaft, 2013). Although UNESCO inscription is without doubt an important tool in protecting outstanding natural and cultural resources, same cannot be said regarding importance for the overall destination development. Destinations like Middle-Rhine Valley need to purposefully integrate their natural and cultural resources to both ensure their sustainability but also offer memorable tourist experience for various audiences. In fact, a differentiated regional approach based on sustainability can serve a function of integrating wine attributes with distinctive cultural heritage, similarly to the function of a regional wine route (Bruwer, 2003).

\section{CONCLUSION}

The results have demonstrated the influence of sustainability on wine buying decision in the tourism context of the Upper Middle Rhein region, however importance of sustainability to the wider wine destination context needs to be further explored. The issue of sustainability should be explored beyond wine tourism only, to include different aspects of a wine destination, as well as to investigate the possible connections to the sustainability of the heritage present at the destination.

The field for cooperation between tourism, wine, and heritage at the Upper Middle Rhine Valley in creating innovative wine tourism solutions has a huge potential as available resource are managed and developed carefully and international awareness of the Loreley and the Rhine romanticism is considerable. The dominance of cars as a mobility solution, followed by boat, should encourage the development of infrastructure in these two areas, and motivate to find sustainable mobility alternatives in the long run. Another issue regarding infrastructure, but also sustainability of small tourism-related businesses, is the relatively high seasonality of wine tourism demand at St. Goar/Loreley. This is an issue not to be overlooked but addressed appropriately in order to ensure the viability of the tourism business at the destination in off- season. Overall, there is an obvious contradiction regarding importance of sustainability on the wine buying decision in the wine tourism context (the fourth most important factor) with the unsustainable distribution of demand for wine destinations (high yearly volatility of demand).

\section{REFERENCES}

Atkin, T., Gilinsky Jr, A., \& Newton, S. (2011). Sustainability in the wine industry: Altering the Competitive Landscape? Paper presented at the 6th AWBR International Conference, Bordeaux Managemet School.

Bruwer, J. (2003). South African wine routes: some perspectives on the wine tourism industry's structural dimensions and wine tourism product. Tourism Management, 24(4), 423-435. doi:10.1016/s0261-5177 (02)00105-X

Delmas, M. A., \& Grant, L. E. (2008). Eco-labeling strategies: the eco-premium puzzle in the wine industry. AAWE Working Paper No. 13.

Dolnicar, S., Crouch, G. I., \& Long, P. (2008). Environment-friendly Tourists: What Do We Really Know About Them? Journal of Sustainable Tourism, 16(2), 197-210.

Dreßler, M. (2016). Strategic Winery Management and Tourism: Value-Added Offerings and Strategies Beyond Product Centrism. In Strategic Winery Tourism and Management (pp. 31-68). Oakville, Canada: Apple Academic Press.

Dressler, M. (2017). Strategic Profiling and the value of wine $\&$ tourism initiatives: exploring strategic grouping of German wineries. International Journal of Wine Business Research.

Germany, F. R. o., Hesse, F. S. o., \& Rhineland-Palatinate, F. S. o. (2002). The Cultural Landscape of the Middle Rhine Valley from Bingen/Rüdesheim to Koblenz. Retrieved from whc.unesco.org/archive/2002/noms /1066.pdf

Gilinsky, J. A., Newton, S. K., Atkin, T. S., Santini, C., Cavicchi, A., Casas, A. R., \& Huertas, R. (2015). Perceived efficacy of sustainability strategies in the US, Italian, and Spanish wine industries. International Journal of Wine Business Research, 27(3), 164-181. doi:10.1108/ijwbr-10-2014-0047 
Goeldner, C. R., \& Ritchie, J. R. B. (2009). Tourism Principles, Practices, Philosophies. Hoboken, New Jersey: John Wiley \& Sons, Inc.

Hall, C. M., \& Prayag, G. (2017). Editorial for special Issue: "Moving beyond the Cellar Door?”. International Journal of Wine Business Research, 338.

Herbert, D. (2001). Literary places, tourism and the heritage experience. Annals of Tourism Research, 28(2), 312-333.

Klohr, B., Fleuchhaus, R., \& Theuvsen, L. (2014). Who is buying sustainable wine? A lifestyle segmentation of German wine consumers. Paper presented at the Academy of Wine Business Research, Geisenheim.

Leiper, N. (1979). The Framework of tourism. Annals of Tourism Research, 6(1), 390-407.

Maksin, M., Pucar, M., Korać, M., \& Milijić, S. (2009). Menadžment prirodnih i kulturnih resursa u turizmu. Beograd: Univerzitet Singidunum.

Ministerium für Wirtschaft, K., Energie und Landesplanung Rheinland-Pfalz. (2013). Masterplan Welterbe Oberes Mittelrheintal- Herausforderungen und Visionen für die zukünftige Entwicklung. Retrieved from Mainz: http://docplayer.org/29281436-Masterplan-welterbe-oberes-mittelrheintal-herausforderungenund-visionen-fuer-die-zukuenftige-entwicklung.html

Paunovic, I. (2014). Branding Serbia as a Tourist Destination on the Global Market. TURIZAM, 59-71.

Paunović, I. (2017). Uporedna analiza održivosti i upravljanja planinskim turizmom na primerima alpske $i$ dinarske regije uz izabrane studije slučajeva. (PhD), Singidunum University, Belgrade. Retrieved from

https://singipedia.singidunum.ac.rs/izdanje/42560-uporedna-analiza-odrzivog-razvoja-planinskog-turizmaalpske-i-dinarske-regije

Paunović, I., \& Jovanović, V. (2017). Implementation of Sustainable Tourism in the German Alps: A Case Study. Sustainability, 9(2). doi:10.3390/su9020226

Paunović, I., \& Radojević, M. (2014). Towards green economy: balancing market and seasonality of demand indicators in serbian mountain tourism product development. Paper presented at the Trends in Tourism and Hospitality Industry, Opatija.

Pechlaner, H., Zacher, D., \& Paunovic, I. (2016). Touristische Stakeholder in der zweiten Reihe. In Gesellschaftlicher Wandel als Hearausforderung im Alpinen Tourismus (pp. 79-97). Berlin: Erich Schmidth Verlag.

Swarbrooke, J., \& Horner, S. (2007). Consumer Behaviour in Tourism, Second Edition. Oxford: Elsevier.

Tourismusstrategie Romantischer Rhein Unsere Handlungsempfehlungen. (2011). Retrieved from https://rlp. tourismusnetzwerk.info/inhalte/tourismus-strategie/regionale-strategien/tourismusstrategie-romantischer-rhein/

UNESCO. (2017). Convention concerning the protection of the world cultural and natural heritage. Krakow, Poland: United Nations Educational, Scientific and Cultural Organization

WTO. (2004). Indicators of sustainable development for tourism destinations: A guidebook. Madrid: World Tourism Organization. 